\title{
Depression, Anxiety and Coping Strategies in Cancer Patients: A Case Control Study
}

\author{
Kanser Hastalarında Depresyon, Anksiyete ve Başa Çıkma \\ Stratejileri: Vaka Kontrol Çalışması
}

\author{
$\underline{\text { Suleyman Ersoy }}{ }^{1}, \underline{\text { Habibe İnci }}^{2}$, Fatih İnci ${ }^{3}$, Velittin Selcuk Engin ${ }^{4}$, Didem Adahan ${ }^{2}$ \\ ${ }^{1}$ University of Health Sciences Umraniye SUAM Department of Family Medicine, İstanbul \\ ${ }^{2}$ Karabük University Faculty of Medicine, Department of Family Medicine \\ ${ }^{3}$ Karabük University Faculty of Medicine Department of Oncology \\ ${ }^{4}$ Melekhatun Family Health Center, Fatih, İstanbul
}

\begin{abstract}
Objectives: Psychiatric disorders frequently accompany chronic diseases especially cancer. The aim of this study was to investigate the depression and anxiety levels and the coping strategies in cancer patients. Materials and Methods: This was a case control study conducted in Karabuk University Research Hospital (KURH) between January 2018 and December 2018. Case group constituted of patients with an established diagnosis of cancer and control group included healthy individuals. Coping Strategies Questionnaire (COPE), Beck Depression Inventory (BDI) and Beck Anxiety Inventory (BAI) were performed for all participants. Statistical analyzes were carried out using Minitab 17 Statistical Software. Case versus control comparison for continues variables was conducted using Mann Whitney U test. Degree of relationship between continues variables were measured using Spearman's rank correlation. Chi-Squared test was used to evaluate cross tabulated categorical data.

Results: 94 individuals were included in the study. Both cancer and control groups consisted of 23 males and 24 females. Mean age was found $59.77 \pm 12.01$ years for cancer patients and 59.06 \pm 12.36 for control group. BDI and BAI scores of the patients were significantly higher compared to healthy individuals. Considering the cut-off values; $60 \%(28 / 47)$ of the cancer patients were found depressed and $62 \%(29 / 47)$ of them were found to have anxiety while in the control group both the depression and anxiety prevalence was $28 \%(13 / 47)(\mathrm{p}=0.004$ and $\mathrm{p}=0.002$ respectively). Both groups were similar regarding the coping strategies total score $(\mathrm{p}=0.779)$. Turning to religion, humor, mental disengagement, denial and substance use were seen more frequently in cancer patients compared to control group $(\mathrm{p}=0.004, \mathrm{p}=0.001, \mathrm{p}=0.005$, $\mathrm{p}=\mathrm{o.001}$ and $\mathrm{p}=\mathbf{0 . 0 0 4}$ respectively); whereas active coping, restraint coping, acceptance and behavioral disengagement were significantly more frequent in control group $(\mathrm{p}=0.001, \mathrm{p}=0.039, \mathrm{p}=0.026$ and $\mathrm{p}=0.055$ respectively).

Humor, mental disengagement, denial and substance use were positively correlated with BDI scores $(\mathrm{r}=0.30 \mathrm{p}=0.003, \mathrm{r}=0.38 \mathrm{p}=0.001, \mathrm{r}=0.29 \mathrm{p}=0.004, \mathrm{r}=0.22 \mathrm{p}=0.03$ respectively). Turning to religion, humor, mental disengagement and substance use were positively correlated with BAI scores $(\mathrm{r}=0.24 \mathrm{P}=0.015$, $\mathrm{r}=0.25 \mathrm{p}=0.013, \mathrm{r}=0.31 \mathrm{p}=0.001, \mathrm{r}=0.23 \mathrm{p}=0.024$ respectively).

Conclusion: The results of the current study revealed that cancer patients had higher levels of depression and anxiety compared to healthy individuals and they had higher risk of being depressed or anxious. Furthermore, the patients developed different strategies in order to cope with the burden of this catastrophic disease. Therefore, cancer is a multifaceted condition which must be approached in a multidimensional manner, by taking psychological features of each individual into account.

Keywords: Anxiety, depression, coping strategies, cancer
\end{abstract}

\section{Öz}

Amaç: Psikiyatrik rahatsızlıklar, kanser başta olmak üzere kronik hastalıklara sıklıkla eşlik eder. Bu çalışmada kanser hastalarındaki depresyon ve anksiyete düzeylerini ve bașa çıkma yöntemlerini araştırmayı amaçladık.

Materyal ve Metot: Vaka kontrol çalışmamızı Karabük Üniversitesi Eğitim ve Araștırma Hastanesinde Ocak 2018 ile Aralık 2018 tarihleri arasında gerçekleștirdik. Vaka grubunu kanser tanısı almış hastalar oluștururken, kontrol grubu olarak da sağlıklı bireyler çalıșmaya dahil edildi. Cope başa çıkma ölçeği (COPE), Beck Depresyon Ölçeği (BDI) ve Beck Anksiyete Ölçeği (BAI)tüm katılımcılara uygulandı. Çalışmanın istatistik analizleri Minitab 17 programı ile yapıldı. Vaka grubu ile kontrol grubunun 
karşılaştırılmasında Mann Whitney U test kullanıldı. Sürekli değişkenler arasındaki korelasyon Spearman's rank korelasyon testi kullanılarak araştıııldı. Kategorik değişkenlerin karşılaştırılmasında Kikare testi kullanıldı.

Bulgular: Çalışmaya 94 kişi dahil edildi. Hem hastalar hem de kontrol grubu 23 erkek ve 24 kadından oluşmaktaydı. Yaş ortalaması kanser hastalarında 59,77 \pm 12,01, kontrol grubunda 59,06 $\pm 12,36$ yıldı. Hastaların BDI ve BAI skorları sağlıklı bireylere kıyasla anlamlı derecede yüksek bulundu ( $<<0,001)$. Cutoff değerleri dikkate alındığında; hastaların \%6o'ı (28/47) depresif bulunurken anksiyete oranı \% 62 (29/47) bulundu. Sağlıklı bireylerde ise hem depresyon hem de anksiyete prevalansı \% 28 (13/47) bulundu (sırasıyla $\mathrm{p}=0,004$ ve $\mathrm{p}=0,002)$. Başa çıkma ölçeği total skoru her iki grubun benzerdi $(\mathrm{p}=0,779)$. Bașa çıkma davranışlarından; dini bașa çıkma, șakaya vurma, zihinsel boș verme, inkar ve madde kullanımı kanser hastalarında kontrol grubuna kıyasla daha sık rastlanırken (sırasıyla $\mathrm{p}=0,004, \mathrm{p}=0,001, \mathrm{p}=\mathrm{0}, 005$, $\mathrm{p}=0$,oo1 ve $\mathrm{p}=0,004)$; aktif başa çıkma, kısıtlı başa çıkma, kabullenme ve davranışsal boș verme kontrol grubunda daha sıktı (sırasıyla $\mathrm{p}=0,001, \mathrm{p}=0,039, \mathrm{p}=0,026 \mathrm{ve} \mathrm{p}=0,055$ ). Şakaya vurma, zihinsel boş verme, inkar ve madde kullanımı ile BDI skorları arasında pozitif korelasyon saptanırken (sırasıyla $r=0,30$ $\mathrm{p}=0,003, \mathrm{r}=0,38 \mathrm{p}=0,001, \mathrm{r}=0,29 \mathrm{p}=0,004, \mathrm{r}=0,22 \mathrm{p}=0,03)$; dini başa çıkma, şakaya vurma, zihinsel boş verme ve madde kullanımıyla da BAI skorları arasında pozitif korelasyon saptandı (sırasıyla $\mathrm{r}=\mathbf{0 , 2 4}$ $\mathrm{p}=0,015, \mathrm{r}=0,25 \mathrm{p}=0,013, \mathrm{r}=0,31 \mathrm{p}=0,001, \mathrm{r}=0,23 \mathrm{p}=0,024)$.

Sonuç: Bu çalışmamızda ortaya koyduğumuz bulgular kanser hastalarının sağlıklı bireylere oranla daha yüksek seviyede depresyon ve anksiyeteye sahip olduklarını ve depresyon ve anksiyeteye girme risklerinin daha fazla olduğunu göstermektedir. Ayrıca kanser hastaları bu yıkıcı hastalıkla başa çıkabilmek için sağlıklı bireylerden farklı başa çıkma yöntemlerine bașvurmaktadır. Kanser, hasta bireylerin psikolojik özelliklerinin göz önünde bulundurulması ve multidisipliner yaklaşılması gereken çok yönlü bir hastalıktır.

Anahtar kelimeler: Anksiyete, depresyon, başa çıkma yöntemleri, kanser

Correspondence / Yazıșma Adresi:

Dr. Suleyman Ersoy

University of Health Sciences Umraniye SUAM, Department of Family Medicine, İstanbul

e-mail: suleymanersoy@gmail.com

Date of submission: 29.06.2019

Date of admission: 07.082019

\section{Introduction}

Cancer is the second most common life-threatening disease following cardiovascular diseases and one of the main public health problems in countries of all income levels. Based on GLOBOCAN estimates, about 14.1 million new cancer cases and 8.2 million deaths occurred in 2012 worldwide. ${ }^{1}$ As population ages and known risk factors of industrial communities such as smoking, overweight, physical inactivity, and unsafe reproduction becomes more common, cancer cases are also expected to increase correspondingly. ${ }^{2}$

Psychiatric disorders frequently accompany chronic diseases and this is especially true for cancer patients. The most common comorbidity is major depression. While lifetime prevalence of psychiatric co-morbidities in cancer patients is $30-40 \%$, the prevalence of major depression in patients with cancer is about 22\%.3 Anxiety often accompanies cancer as well. A great proportion of cancer patients display anxiety symptoms with increasing prevalence as they approach to terminal stage. The rate of anxiety symptoms ranged between $18.6 \%$ and $33.4 \% .{ }^{4}$ Both anxiety and depression may interfere with the quality of life, adherence to treatment, response to treatment and severity of the disease in these patients. 
Coping may be described as resistance of the individual to stressing events or conditions, as well as cognitive, emotional and behavioral responses to these circumstances. ${ }^{5}$ When an individual faces an ailment that probably will last long and affect life quality and threaten accomplishment of assigned physical and social tasks, he/she is expected to develop attitudes in order to alleviate or overcome the undesired outcomes of the disease. There are three main groups of coping patterns: Active coping, planning, restraint coping (avoiding confrontation). Demanding industrial social support and aborting competing activities are problem-focused coping strategies. There are also emotion-focused coping strategies that consist of positive reinterpretation, turning to religion, humor, demanding emotional social support, and acceptance. As a last subgroup; mental and/or behavioral disengagement, focusing on and venting of emotions, denial, and substance abuse are non-functional coping strategies. ${ }^{6}$

In the current study we aimed to investigate the depression and anxiety levels and the coping strategies in cancer patients by comparing them with healthy individuals. We also searched whether coping was correlated with depression or anxiety in these patients.

\section{Material and Methods}

This was a case control study conducted in Karabuk University Research Hospital (KURH) between January 2018 and December 2018. Case group consisted of the cancer patients who applied to Oncology Clinic of KURH. The patients who were at the terminal stage and who were not able to answer the test questions were excluded. Healthy individuals who applied to Family Medicine Polyclinic of KURH were enrolled as control group. The individuals who were previously diagnosed a chronic disease, a psychiatric disorder or on daily medication were excluded. All participants were included in the study after their informed consent was obtained. Ethical approval was obtained from Karabuk University Clinical Trials Ethics Committee. All procedures performed in the current study were in accordance with the ethical standards of the institutional and/or national research committee and with the 1964 Helsinki declaration and its later amendments or comparable ethical standards.

After sociodemographic information was obtained, Coping Strategies Questionnaire (COPE), Beck Depression Inventory (BDI) and Beck Anxiety Inventory (BAI) were applied face to face to all of the participants by one of the researchers.

COPE Assessment Scale: It was developed by Carver and colleagues in 1989. ${ }^{7}$ Agargün and colleagues translated the scale into Turkish and conducted validity and reliability studies for the scale. ${ }^{8}$ This scale aims to examine how people react when confronted with a difficult situation that causes anxiety. The scale consists of 60 questions and 15 sub-scales. Each of these sub-scales gives information about different strategies for coping with stress.

Beck Depression Inventory (BDI): This self-assessment scale, developed by Beck et al. to measure emotional, cognitive, somatic and motivational symptoms of depression. It includes 21 items each of which is scored between $0-3$. The validity and reliability of the Turkish language version of BDI was conducted by Hisli. ${ }^{9}$ From o to 10 points in this scale is interpreted as absence of depressive symptoms, while between 11 and 17 indicates mild depressive symptoms and 18 to 23 moderate depressive mood. Scoring 24 or more points in this scale is suggestive of major depression. 
Beck Anxiety Inventory (BAI): This is a 21-item scale of self-assessment which has been developed by Beck and colleagues to determine the frequency of anxiety symptoms experienced by a person. Validity and reliability of the Turkish language version was conducted by Ulusoy and colleagues. ${ }^{10}$ This inventory is scored in four categories: 0 to 7 points, 8 to 15 points, 16 to 25 points and 26 to 63 points. These categories are indicative of minimal anxiety, mild anxiety, moderate anxiety and severe anxiety, respectively.

Statistical Analysis: Before statistical analysis, distributional properties of data were evaluated using Anderson-Darling normality test. Descriptive statistics obtained. Case versus control comparison for continues variables was conducted using Mann Whitney U test. Degree of relationship between continues variables were measured using Spearman's rank correlation. Chi-Squared test was used to evaluate cross tabulated categorical data. All analyzes were carried out using Minitab 17 Statistical Software.

\section{Results}

Total number of participants was 94. Both cancer and control groups consisted of 23 males and 24 females. Mean age of the cancer patients was 59.77 \pm 12.01 years while it was found $59.06 \pm 12.36$ for control group. Most of the participants were married ( $92 \%$ of the cancer patients, $96 \%$ of the control group). Demographic features of the both groups were expressed in Table 1 . However, cancer patients were less educated ( $\mathrm{p}<0.001)$ and less professional $(\mathrm{p}<\mathrm{0.001})$ in significantly higher frequencies compared to control group, while body weights of cancer group were significantly lower $(\mathrm{p}=0.029)$.

Table 1. Demographic features of the participants

\begin{tabular}{|l|c|c|c|}
\hline Features & Patients & Control & P \\
\hline Gender, n (\%) & $23(46)$ & $23(46)$ & \\
Female & $24(48)$ & $24(48)$ & 0.910 \\
Male & $59.77 \pm 12.01$ & $59.09 \pm 12.36$ & 0.810 \\
\hline Age (years) & $164.38 \pm 7.57$ & $166.83 \pm 7.54$ & 0.149 \\
\hline Height (cm) & $72.36 \pm 13.89$ & $77.85 \pm 11.68$ & 0.029 \\
\hline Weight (kg) & & & \\
\hline Marital, n (\%) & $43(92)$ & $45(96)$ & 0.701 \\
Married & $2(4)$ & $1(2)$ & \\
Single & $2(4)$ & $1(2)$ & \\
Widow & $7(15)$ & $4(8)$ & \\
\hline Education, n (\%) & $21(44)$ & $8(17)$ & \\
Literal & $7(15)$ & $5(11)$ & \\
Primary & $7(15)$ & $12(26)$ & \\
Secondary & $5(11)$ & $18(38)$ & \\
Lyceum & & $14(30)$ & \\
University & $20(43)$ & 0.001 \\
\hline Occupation, n (\%) & $2(4)$ & $13(28)$ & \\
Housewife & $2(4)$ & $2(4)$ & \\
Student & $1(2)$ & $6(13)$ & \\
Clerk & $3(7)$ & $12(25)$ & \\
Worker & $19(40)$ & & \\
Trade work & & & \\
Retired & & & \\
\hline
\end{tabular}


Both groups were similar regarding the coping strategies total score $(\mathrm{p}=0.779)$ No significant differences were detected as well between the groups in problem and emotion focused coping strategies. However, cancer patients had significantly higher scores of non-functional coping strategies. Coping strategies in the cancer and control groups were compared for each of the 15 subscales as well. Turning to religion, humor, mental disengagement, denial and substance use were seen more frequently in cancer patients compared to control group $(\mathrm{p}=0.004, \mathrm{p}=0.001, \mathrm{p}=0.005, \mathrm{p}=0.001$ and $\mathrm{p}=0.004$ respectively); whereas active coping, restraint coping, acceptance and behavioral disengagement were significantly more frequent in control group $(\mathrm{p}=0.001, \mathrm{p}=0.039$, $\mathrm{p}=0.026$ and $\mathrm{p}=0.055$ respectively). No significant differences were detected in the rest of coping strategies between two groups (Table 2 ).

Table 2. Comparison of the coping strategies of the Patient and Control groups according to COPE Assessment Scale

\begin{tabular}{|l|c|c|c|}
\hline & Patients & Control & \multirow{2}{*}{ P $^{*}$} \\
\hline Problem focused coping strategies & Median (min-max) & Median (min-max) & \\
\hline Active coping & $12.0(8.0-17.0)$ & $14.0(10.0-16.0)$ & \multirow{2}{*}{$\mathbf{0 . 0 0 1}$} \\
\hline Planning & $10.0(5.0-16.0)$ & $10.0(7.0-13.0)$ & \multirow{2}{*}{0.089} \\
\hline Restraint coping & $12.0(6.0-18.0)$ & $13.0(9.0-16.0)$ & $\mathbf{0 . 0 3 9}$ \\
\hline Seeking instrumental social support & $12.0(7.0-16.0)$ & $12.0(7.0-16.0)$ & 0.761 \\
\hline Suppression of competing activities & $10.0(7.0-16.0)$ & $12.0(6.0-15.0)$ & 0.251 \\
\hline Emotion focused coping strategies & $57.0(34.0-80.0)$ & $59.0(35.0-68.0)$ & 0.172 \\
\hline Positive reinterpretation & $13.0(8.0-16.0)$ & $14.0(10.0-16.0)$ & 0.140 \\
\hline Turning to religion & $16.0(5.0-18.0)$ & $14.0(4.0-16.0)$ & $\mathbf{0 . 0 0 4}$ \\
\hline Humor & $8.0(4.0-16.0)$ & $6.0(4.0-9.0)$ & $\mathbf{0 . 0 0 1}$ \\
\hline Seeking of emotional social support & $12.0(6.0-16.0)$ & $12.0(5.0-15.00)$ & 0.277 \\
\hline Acceptance & $9.0(6.0-17.0)$ & $11.0(4.0-16.0)$ & $\mathbf{0 . 0 2 6}$ \\
\hline Non-functional coping strategies & $40.0(30.0-80.0)$ & $38.0(27.0-46.0)$ & $\mathbf{0 . 0 2 0}$ \\
\hline Mental disengagement & $7.0(4.0-16.0)$ & $6.0(4.0-10.0)$ & $\mathbf{0 . 0 0 5}$ \\
\hline Focusing and venting of emotions & $4.0(4.0-16.0)$ & $4.0(4.0-8.0)$ & 0.980 \\
\hline Denial & $8.0(4.0-16.0)$ & $5.0(4.0-12.0)$ & $\mathbf{0 . 0 0 1}$ \\
\hline Substance use & $9.5(5.0-16.0)$ & $8.0(4.0-12.0)$ & $\mathbf{0 . 0 0 4}$ \\
\hline Behavioral disengagement & $10.0(7.0-16.0)$ & $12.0(6.0-16.0)$ & $\mathbf{0 . 0 5 5}$ \\
\hline
\end{tabular}

*: Obtained from Man Whitney U test 
The mean BDI scores were $15.96 \pm 9.24$ for the patient group and $6.72 \pm 5.15$ for the control group $(\mathrm{p}<0.001)$. Similarly, BAI scores of the patients were also significantly higher compared to healthy individuals (14.23 \pm 8.97 vs. $5.93 \pm 5.24, \mathrm{p}<0.001)$ (Table 3 ).

Table 3. Depression and Anxiety scores of the patients and control group

\begin{tabular}{|l|c|c|c|c|c|}
\hline Inventory & Group & $\mathbf{n}$ & Mean+SD & Median (min-max) & $\mathbf{P}^{*}$ \\
\hline \multirow{3}{*}{ BDI } & Patients & 47 & $15.96+9.24$ & $15(6-40)$ & \\
\cline { 2 - 6 } & Control & 47 & $6.72+5.15$ & $4(2-22)$ & $<0.001$ \\
\hline \multirow{3}{*}{ BAI } & Patients & 47 & $14.23+8.97$ & $13(5-36)$ & \\
\cline { 2 - 6 } & Control & 47 & $5.93+5.24$ & $4(2-28)$ & $<0.001$ \\
\hline
\end{tabular}

*: Obtained from Man Whitney U test

Considering the cut-off values of BDI; 6o\% (28/47) of the cancer patients were found depressed while $40 \%(19 / 47)$ of them were normal. In the control group, the depression prevalence was $28 \%(13 / 47)$ whereas $72 \%(34 / 47)$ of the participants were found normal ( $\mathrm{p}=0.004)$ (Table 4). Among the depressed, 15 cancer patients were having mild depression and 13 patients moderate/severe depression while in the control group, 8 of the healthy individuals were found to have mild and 5 of them moderate/severe depression (Table 4). Post-hoc test (adjusted residual in Chi-square test $>1.96$ or adjusted residual in Chi-square test $<-1.96$ ) revealed that normal and moderate/severe BDI levels are significantly associated with health status (i.e. patient and control groups).

As for BAI; $62 \%(29 / 47)$ of the cancer patients were found to have anxiety while $38 \%$ (18/47) of them were normal. In the control group, the anxiety prevalence was $28 \%$ (13/47) whereas $72 \%(34 / 47)$ of the participants were found normal ( $\mathrm{p}=0.002$ ) (Table 4 ). Among the anxious subjects, 15 cancer patients were having mild anxiety and 14 patients moderate/severe anxiety while in the control group, 9 of the healthy individuals were found to have mild and 4 of them moderate/severe anxiety (Table 4 ). Post-hoc test (adjusted residual in Chi-square test $>1.96$ or adjusted residual in Chi-square test < 1.96) revealed that normal and moderate/severe BAI levels are significantly associated with health status (i.e. patient and control groups).

Table 4. Depression and Anxiety Levels of the patients and control group

\begin{tabular}{|c|c|c|c|c|}
\hline Inventory & Level & Patients (n) & Control (n) & $\mathbf{P}^{*}$ \\
\hline \multirow{3}{*}{ BDI } & Normal & 19 & 34 & \multirow{3}{*}{0.004} \\
\hline & Mild depression & 15 & 8 & \\
\hline & Moderate/Severe depression & 13 & 5 & \\
\hline \multirow{3}{*}{ BAI } & Normal & 18 & 34 & \multirow{3}{*}{0.001} \\
\hline & Mild anxiety & 15 & 9 & \\
\hline & Moderate/Severe anxiety & 14 & 4 & \\
\hline
\end{tabular}

*: Obtained from Chi-squared test 
We also checked whether there were any correlations between the subscales of COPE and BDI or BAI scores of the patients. Humor, mental disengagement, denial and substance use were positively correlated with BDI scores $(r=0.30 \mathrm{p}=0.003, \mathrm{r}=0.38$ $\mathrm{p}=0.001, \mathrm{r}=0.29 \mathrm{p}=0.004, \mathrm{r}=0.22 \mathrm{p}=0.03$ respectively) whereas active coping was negatively correlated $(\mathrm{r}=-0.23 \mathrm{p}=0.024)$. Turning to religion, humor, mental disengagement and substance use were positively correlated with BAI scores $(r=0.24$ $\mathrm{p}=0.015, \mathrm{r}=0.25 \mathrm{p}=0.013, \mathrm{r}=0.31 \mathrm{p}=0.001, \mathrm{r}=0.23 \mathrm{p}=0.024$ respectively) while active coping and restraint coping were negatively correlated $(\mathrm{r}=-0.30 \mathrm{p}=0.002, \mathrm{r}=-0.27 \mathrm{p}=0.006$ respectively).

\section{Discussion}

The results of the current study revealed that cancer patients had higher scores in depression and anxiety scales compared to healthy individuals, thus they had higher risk of being depressed or anxious. Several studies conducted on various chronic disorders concluded that depression and anxiety accompany these diseases as hormonal disorders such as hypothyroidism ${ }^{11}$ and organ failures such as chronic renal failure. ${ }^{12}$

Cancer is a chronic disease which, apart from the pain that it inflicts, also recalls painful demise, induces the feelings of guilt and anxiety as well as panic and chaos. ${ }^{13}$ As a result; it paves the way for the development of depressive conditions. Reports of depression in cancer patients were divergent, ranging in frequency from $4.5 \%$ to $58.0 \% .^{14} \mathrm{Kutlu}$ and colleagues reported $21.6 \%$ mild and $12.7 \%$ major depression in cancer patients. ${ }^{15}$ Similarly, Derogatis and colleagues reported a rate of $13 \%$ for major depression in 215 cancer patients. ${ }^{16}$ Valente and colleagues suggested that one in every four cancer patients had the probability of developing major depressive disorder in any stage of the disease. ${ }^{17}$ In our study, the BDI scores suggested a rate of depression as high as $60 \%$ among cancer patients, in which the shares of mild, moderate and severe presentation were found to be $32 \%, 18 \%$ and $10 \%$ respectively.

Depression is a serious health problem that affects not only life quality, but also morbidity and mortality. In a study conducted with 10000 cancer patients in a 8 years period, comorbidity of cancer and MD was associated with increased mortality. ${ }^{18}$ There are also studies reporting that untreated depression accelerates the progression of the disease. ${ }^{19}$ Therefore depression should be investigated and taken into account during the therapeutic process of these patients.

In the current study the prevalence of anxiety was found $62 \%$ among cancer patients; $32 \%$ of them having mild, $18 \%$ moderate and $\% 12$ severe anxiety. Aydogan and colleagues reported similar results: They found these rates as high as $65 \%, 31 \%, 23 \%$ and $11 \%$, respectively. ${ }^{20}$ In another study from Turkey, lower anxiety rate $(28 \%)$ was reported while depression prevalence (\%64) was consistent with our results. ${ }^{21}$ Karakoyun-Celik and colleagues reported that depression and anxiety both were associated with worse outcomes in terms of life quality and coping with disease functionally in patients with breast cancer. ${ }^{22}$ Chemotherapy also was found to have an impact on the levels of anxiety and depression in cancer patients. ${ }^{23}$ Like depression, Anxiety also should be taken into consideration in the follow up of the cancer patients 
Any patient who experiences a chronic, life threatening disease such as cancer will need to alleviate it's burden by avoiding some of its unfavorable consequences and if at all possible, the disease in itself. This reaction becomes crystallized in coping strategies. To evaluate the efficiency of treatment as well as outcomes more properly, patient's individual coping strategies must be well understood. In our study turning to religion was found to be the most frequent coping strategy in cancer patients and it was significantly higher when compared to healthy individuals. It was still the most frequent coping method when the overall participants of the study were evaluated. This finding was compatible with different studies. Hiçdurmaz and Cetinkaya reported in their studies that turning to religion was the most frequently used coping method in chronic renal failure patients. ${ }^{24,} 25$ In another study, authors concluded that religious attitudes had the greatest impact on coping with stress, as they found that it determined which coping method the stressed individual would choose. ${ }^{26}$

A study conducted on cancer patients reported that turning to religion was the main coping strategy used by the patients and the most used religious way of coping with cancer was prayer and reading Koran. ${ }^{27}$ In a study from Turkey, depressive patients were contemplating death in a higher rate. Interestingly, none of the patients had ever planned or attempted suicide. Authors commented on this finding and suggested that majority in Turkey had religious beliefs and it prevented them from suicide, as committing suicide is strictly forbidden in Islam. ${ }^{3}$

Following turning to religion, positive reinterpretation, seeking instrumental social support, seeking emotional social support and active coping were the most used coping strategies by cancer patients. In a study which was conducted on chronic renal patients, it was reported that the coping strategies most commonly used by the hemodialysis group were seeking of instrumental social support followed by turning to religion and seeking of emotional social support whereas the peritoneal dialysis group mostly used religious coping and seeking of instrumental social support. ${ }^{12}$ In a similar study conducted in Turkish cancer patients, social support seeking was found to be the mostly used coping strategy. As a comment, the authors emphasized the strong family and social network in Turkey, which is very sensitive to any stressful condition that happened to one of its members. This feature enables the patient to get material as well as emotional help from their relatives when needed. ${ }^{28}$ We believe this is also the case in our study, since both seeking instrumental and emotional social support turned out to be among the most frequent coping strategies. A study on patients with gynecologic cancer showed that higher perceptions of social support were associated with greater fighting spirit and lesser helplessness or hopelessness ${ }^{29}$.

Both anxiety and depression scores in our study were positively correlated with coping subscales of humor, mental disengagement and substance use. However, turning to religion which was the most frequent coping method was positively correlated with anxiety scores but not with depression. This might be explained with the type of anxiety which has been termed as death anxiety in the literature and accepted to be the main cause of anxiety in cancer patients as could be seen from the findings that anxiety prevalence increases in the terminal stage. ${ }^{30}$ Most of the patients feel horrified of the thought of close and inevitable death, although some others have more soothing conceptions of death, ie. It's an elemental part of living. ${ }^{31}$ Not only thoughts of death, but also physical complaints increase as disease progress. ${ }^{32}$ Additionally, patients feel 
themselves more guilty because of their family's burden. ${ }^{33}$ These factors render the patient more susceptible to death anxiety. Considering the prominent role of resorting to religion in coping with cancer which is supported also by findings in this study, we may conclude that it is even more important for end stage cancer patients. Studies of death anxiety generally enrolled end stage cancer patients. These patients had death anxiety at a scale of moderate to high, and rates range from $32 \%$ to $45 \% .34,35$

If we evaluate the results of the current study from the perspective of biopsychosocial model we can witness the fact that not only cancer but almost all of the chronic disorders are accompanied with psychological and social components. Therefore, the patients suffering from any of these diseases must be treated in a multidisciplinary way. Health professionals like oncologists, palliative care specialists, psychiatrists, psychologists and experienced nurses are imperative in supportive care of these patients. Nonetheless, as this disease poses both physical and emotional challenges, there are more help that only close relatives and social network can offer. The patient needs motivation to hold on, needs instant help in many cases and needs to alleviate concerns and fears by sharing feelings or simply by small talk. To help the patient undertake the burden of this multifaceted challenge, social support must include the involvement of close ones as well as spiritual aid when needed. Results of this study also underlines the importance of religious services for these kinds of patients.

In conclusion; our results revealed that depressive symptomatology as well as anxiety symptoms was higher in cancer patients compared to healthy individuals. Additionally, cancer patients develop different coping strategies in the disease process. Religious attitude plays an important role not only in coping strategies, but also in avoiding suicide.

This study supports the evidence which suggests that cancer patients must be approached and treated in a multidimensional manner, taking psychological features of each individual into account.

\section{References}

1. Ferlay J, Soerjomataram I, Ervik M et al. GLOBOCAN 2012 vı.o, Cancer Incidence and Mortality Worldwide: IARC CancerBase No. 11, https://publications.iarc.fr/Databases/IarcCancerbases/GLOBOCAN-2012-Estimated-Cancer-Incidence-Mortality-And-PrevalenceWorldwide-In-2012-V1.0-2012, Erişim Tarihi:01.06.2019.

2. Torre LA, Siegel RL, Ward EM, Jemal A. Global Cancer Incidence and Mortality Rates and Trends-An Update. Cancer Epidemiol Biomarkers Prev. 2016;25(1):16-7.

3. Tokgöz G, Yaluğ İ, Özdemir S, Yazici A, Uygun K \& Aker T. Kanser hastalarında majör depresyon yaygınlığı ve ilișkili etkenler. Anadolu Psikiyatri Dergisi, 2008;9(2):59-66.

4. Tang ST, Longitudinal analysis of severe anxiety symptoms in the last year of Life among Patients with Advanced Cancer: relationships with Proximity to Death, Burden, and Social support. Journal of the National Comprehensive Cancer Network, 2016;14(6):727-34.

5. Folkman S, Lazarus RS, Gruen RJ, DeLongis A. Appraisal, coping, health status, and psychological symptoms. J Pers Soc Psychol 1986;50:571-9.

6. Erdem M, Çelik C, Doruk A, Özgen F. Yaygın anksiyete bozukluğunda başa çıkma tutumları. Anatol J Clin Investig 2008;2(3):101-5.

7. Carver CS, Scheier MF \& Weintraub JK. Assessing coping strategies: a theoretically based approach. Journal of personality and social psychology. 1989;56(2):267.

8. Agargün MY, Besiroglu L, Kiran ÜK, Özer ÖA \& Kara H. COPE (Basa Çikma Tutumlarini Degerlendirme Ölçegi): Psikometrik özelliklere iliskin bir ön çalisma/The psychometric properties of 
the COPE inventory in Turkish sample: a preliminary research. Anadolu Psikiyatri Dergisi 2005;6(4):221.

9. Hisli N. Beck depresyon envanterinin üniversite ögrencileri için geçerliliği, güvenilirliği.(A reliability and validity study of Beck Depression Inventory in a university student sample). J Psychol 1989;7:3-13.

10. Ulusoy M, Sahin NH \& Erkmen H. The Beck Anxiety Inventory: Psychometric Properties. Journal of cognitive psychotherapy 1998;12(2):163-72.

11. Ersoy S, Engin VS. Depresif semptomatoloji için bağımsız risk faktörü olarak hipotiroidi. Smyrna Tip Dergisi 2014;2:22-9.

12. Baykan H, Yargic I. Depression, anxiety disorders, quality of life and stress coping strategies in hemodialysis and continuous ambulatory peritoneal dialysis patients. Klinik Psikofarmakoloji Bülteni-Bulletin of Clinical Psychopharmacology 2012;22(2):167-76.

13. Özkan S. Kanser Hastasında Psikiyatrik ve Psikososyal Destek. In: Onat H ve Molines MN (Eds.), Kanser Hastasına Yaklaşım Tanı, Tedavi Ve Takipte Sorunlar. İstanbul: Nobel Tıp Kitabevleri; 2002:345-54.

14. Elbi H. Kanser ve depresyon. Psikiatri Dünyası 2001;5:5-10.

15. Kutlu R, Çivi S, Börüban MC, Demir A. Depression and the Factors Affecting the Quality of Life in Cancer Patients. Selçuk Üniversitesi Tip Dergisi, 2011;27(3):149-53.

16. Derogatis LR. The prevalence of psychiatric disorders among cancer patients. JAMA. 1983;249(6):751-7.

17. Valente SM, Saunders F. Diagnosis and treatment of major depression among people with cancer. Cancer Nursing 1997;20:168-77.

18. Onitilo AA, Nietert PJ, Egede LE. Effect of depression on all cause mortality in adults with cancer and differential effects by cancer site.Gen Hosp Psychiatry 2006;28:396-402.

19. Spiegel D, Giese-Davis J. Depression and cancer:mechanisms and disease progression. Biol Psychiatry 2003;54:269-82.

20. Kanser hastalarında depresyon ve anksiyete düzeyleri ve hastalıkla başa çıkma tutumlarının ilișkisi. Türkiye Aile Hekimliği Dergisi, 2012:16(2):55-6o.

21. Kelleci M, Aydın D, Sabancıoğulları S, Doğan S. Hastanede yatan hastaların bazı tanı gruplarına göre anksiyete ve depresyon düzeyleri. Klinik Psikiyatri 2009;12:90-8.

22. Karakoyun-Celik O, Gorken I, Sahin S, Orcin E, Alanyali H, Kinay M. Depression and anxiety levels in woman under follow-up for breast cancer: relationship to coping with cancer and quality of life. Med Oncol 2010;27(1):108-13.

23. Alacacıoğlu A, Yavuzșen T, Diriöz M, Yeșil L, Bayrı D, Yılmaz U. Kemoterapi alan kanser hastalarında anksiyete düzeylerindeki değișiklikler. Uluslararası Hematoloji-Onkoloji Dergisi 2007;17(2): 87-93.

24. Hiçdurmaz D. Hemodiyaliz ve sürekli ayaktan periton diyalizi uygulanan hastaların stresle baş etme biçimlerinin belirlenmesi. Yüksek Lisans Tezi, Hacettepe Üniversitesi Sağlık Bilimleri Enstitüsü, Ankara; 2005.

25. Çetinkaya S, Nur N, Ayvaz A, Özdemir D. Bir üniversite hastanesinde hemodiyaliz ve sürekli ayaktan periton diyalizi hastalarında depresyon, anksiyete düzeyleri ve stresle başa çıkma tutumları. Nöropsikiyatri Arşivi 2008;45(3):78-84.

26. Kavas E. Dini tutum stresle başa çıma ilişkisi. Dumlupınar Üniversitesi Sosyal Bilimler Dergisi 2013;(37): 10 .

27. Çiftçi A. Ağır hastalıklarla başa çıkmada dinin rolü: Kanser hastalığı örneği. Marmara Üniversitesi İlahiyat Fakültesi, SBE (Yayınlanmamıș Yüksek Lisans Tezi) İstanbul; 2007. katalog.marmara.edu.tr/eyayin/tez/Too56063.pdf , Erişim Tarihi:01.06.2019.

28. Karabulutlu, EY, Bilici M, Çayır K, Tekin SB, Kantarcı R. Coping, Anxiety and Depression in Turkish Patients with Cancer. European Journal of General Medicine 2010;7(3):296-302.

29. Yagmur Y, Duman M. The relationship between the social support level perceived by patients with gynecologic cancer and mental adjustment to cancer. International Journal of Gynecology \& Obstetrics 2016;134:208-11.

30. Şahan E. Death anxiety in patients with myocardial infarction or cancer. The Egyptian Heart Journal 2018;70(3):143-7.

31. Rasmussen CA, Brems C. The Relationship of Death Anxiety with Age and Psychosocial Maturity. J Psychol 1996;13D(2): 141-4. 
32. Lichtenthal W G, Nilsson M, Baohui Z, et al. Do rates of mental disorders and existential distress among advanced stage cancer patients increase as death approaches?. Psycho-Oncology: Journal of the Psychological, Social and Behavioral Dimensions of Cancer, 2009;18(1):50-61.

33. Engelmann D, Scheffold K, Friedrich M et al. Death-related anxiety in patients with advanced cancer: Validation of the German version of the death and dying distress scale.Journal of Pain and Symptom Management, 2016;52(4):582-7.

34. Lo C, Hales S, Zimmermann C, Gagliese L, Rydall A, Rodin G. Measuring death-related anxiety in advanced cancer: Preliminary psychometrics of the death and dying distress scale. Journal of Pediatric Hematology/Oncology 2011;33:140-5.

35. Neel C, Lo C, Rydall A, Hales S, Rodin G. Determinants of death anxiety in patients with advanced cancer. BMJ Supportive \& Palliative Care 2015;5(4):373-80. 